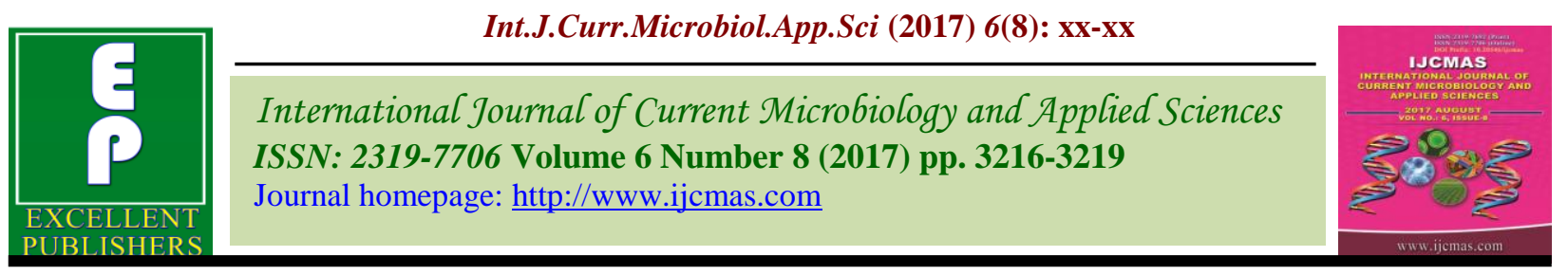

Original Research Article

https://doi.org/10.20546/ijcmas.2017.608.383

\title{
First Report of Corynespora Leaf Spot Caused by Corynespora cassiicola on Chilli in West Bengal, India
}

\author{
Veera Suresh $^{1 *}$, N. Sumalatha ${ }^{2}$, Vikas Kumar Ravat ${ }^{1}$ and Amitava Basu ${ }^{1}$ \\ ${ }^{1}$ Department of Plant Pathology, Bidhan Chandra Krishi Viswavidyalaya, \\ Mohanpur, Nadia741252, West Bengal, India \\ ${ }^{2}$ Department of Plant Pathology, Prof. Jayashanker Telangana State Agricultural University, \\ Hyderabad, Telangana-5000030, India \\ *Corresponding author
}

\begin{tabular}{|c|c|}
\hline & A B S T R A C T \\
\hline Keywords & A Survey was conducted in major chilli growing areas of west Bengal for \\
\hline $\begin{array}{l}\text { Corynespora, } \\
\text { Leaf spot, Chilli } \\
\text { (Capsicum } \\
\text { anпиит L.) }\end{array}$ & $\begin{array}{l}\text { chilli apart from the anthracnose, Alternaria, Choanephora blight a new } \\
\text { disease was observed showing symptoms as dark brown spots on leaf, stem } \\
\text { and fruit on chilli (Capsicum annuum L.) plants in Basantapur, West } \\
\text { Bengal during 2015-2016. The fungus was isolated from collected samples }\end{array}$ \\
\hline Article Info & and proved Koch's postulates by detached leaf technique. The isolated \\
\hline $\begin{array}{l}\text { Accepted: } \\
\text { 26 June } 2017 \\
\text { Available Online: } \\
10 \text { August } 2017\end{array}$ & $\begin{array}{l}\text { pathogen was identified as Corynespora cassiicola on the basis of } \\
\text { morphological and cultural characters of the pathogen. This is the first } \\
\text { report of Corynespora spot caused by } C \text {. cassiicola on chilli in West } \\
\text { Bengal. }\end{array}$ \\
\hline
\end{tabular}

\section{Introduction}

Chilli (Capsicum annuum L.) also known as red pepper is the highest consumed spice in the world, belongs to the family Solanaceae and genus Capsicum. It is an important constituent of many foods, adding flavor, colour, vitamins, pungency and therefore indispensable to the world food industries. Chilli is one of the major cash crops in India and our country is rated to be the second largest exporter in the world.

The crop is mainly grown for its pungent fruits which are used as green and ripe to impart pungency to food. India is the single largest chilli producer contributing for about
$38 \%$ followed by China. In country, West Bengal stands $4^{\text {th }}$ in production $(100,000 \mathrm{MT})$ grown in an area of 63.6 lakh ha with productivity $1.57 \mathrm{MT} / \mathrm{ha}$ followed by Andhra Pradesh, Tamil Nadu and Karnataka (India stat, 2011-12).

In west Bengal good varieties, hybrids and latest technologies available for high chilli production. In spite of that the main constraint for low productivity or quality are due to attack of various diseases on chilli. The Major objective of this study to know most prevalent fungal diseases in chilli in major chilli growing areas of the West Bengal. 
During 2015-2016, a survey was conducted in chilli growing areas, different diseases like Anthracnose, fruit rot, Alternaria, Cercospora leaf spot, Choanephora blight were observed along with those diseases dark brown spots on leaves and black stem lesions on chilli plants were observed in several fields in Basantpur, West Bengal.

The disease incidence range on chilli plants varied from $11 \%$ to $35 \%$ in different fields. The objective of the present study was to determine the causal agent and its identification.

\section{Materials and Methods}

A survey was conducted in Mohanpur, Basanthpur, Haringhata, Jajuli, Kalyani, Laupala in Nadia district of West Bengal.

\section{Collection and Pathogen isolation}

Diseased leaves, stems and fruits with typical symptoms of brown spots were collected from chilli plants during 2015-16. Infected tissues were cut into 2-3 $\mathrm{mm}$ pieces and sterilized with $1 \%$ Sodium hypochlorite solution for 1 min. The samples were then washed three times with sterile distilled water and placed on potato dextrose agar (PDA) and incubated at $25^{\circ} \mathrm{C}$ with a $12-\mathrm{h}$ photoperiod for $3-4$ days

\section{Pathogenicity test}

Pathogenicity test was done by inoculating the isolated fungus through detached leaf technique (Chowdappa et al., (2014). Slight wounding was done on the leaves with the help of sterilized needle and the fungus from the 10 days old culture was placed on the wounded area of the leaves and covered with a moist cotton swab. After inoculation, leaves were kept in sterile Petri plates for 7 days in growth chamber with temperature fixed at 27 $\mathrm{C}$ and RH at 95 per cent. Observed for disease symptom on inoculated samples. And proved the Kochs postulates to confirm the causal agent.

The isolated pathogen was observed under the microscope and purified by hypal tip method. Identification of the pathogen by Culture morphology, conidial morphology and Shape, length and width of conidia were observed by microscopy.

Species identification was based on the morphological and taxonomic keys provided by Wei 1950; Ellis \& Holliday 1971.

\section{Results and Discussion}

\section{Disease symptoms}

The disease symptoms initially appears on young leaves as small brown circular spots, later turned to circular or irregular in shape with white papery centres delimited by dark brown borders. Yellow halos often appeared around the spots. As the disease progressed, some spots gradually enlarged and coalesced, resulting in large irregular lesions with wavy brown margin. Cracking also appears at the center of the leasion at maximum severity of disease symptom. (Fig. a, b \&c)Defoliation of infected leaves was observed in most infected chilli plants. Dark brown spots also appeared on fruits and black lesions appeared on stems. (Kwon et al., 2001)

\section{Fungal isolation and identification}

The fungal Colonies grown on PDA at $25^{\circ} \mathrm{C}$ after 7 days were greybrown to black in colour with circular smooth margin and thinly hairy with velvety mycelial growth (Fig. f). Conidia were clavate or cylindrical, straight or curved, smooth, septate, pale olivaeous brown or brown, solitary or catenate, 53.0$230.5 \times 7.3-18.5 \mu \mathrm{m}$, with $2-14$ pseudosepta (Figure. g). 
Fig.1 a, b, c and d - Leaves and Stem symptomson chilli plant
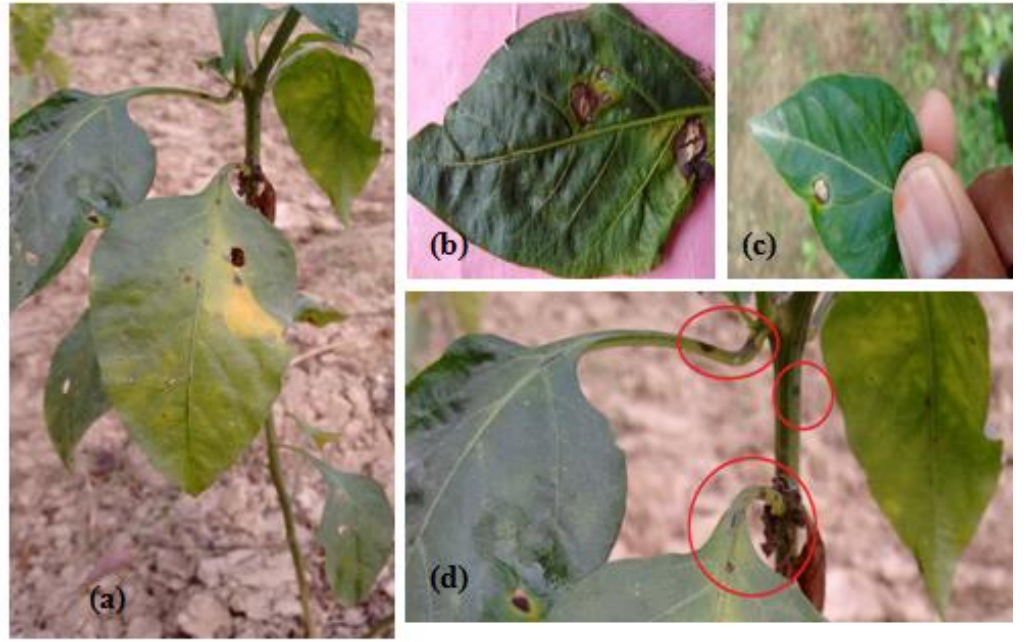

Fig.1 e-pathogenicity test; f-pure culture Corynospora cassicola; g-Conidia of C. cassicola

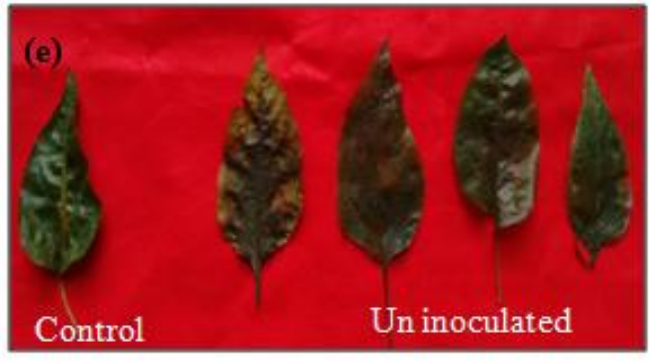

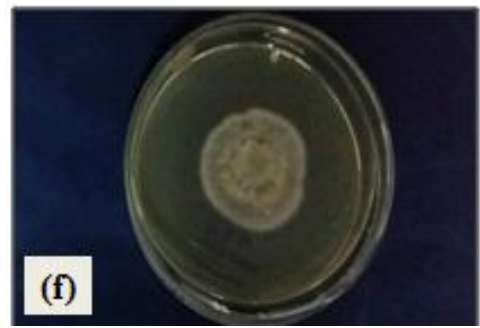

Morphological characteristics of the present fungus were similar to previous descriptions for Corynespora cassiicola (Wei 1950; Ellis \& Holliday 1971).

\section{Pathogenicity test}

The visible symptoms were noticed from $4^{\text {th }}$ day onwards after the inoculation of pathogen. The inoculated chilli leaves were found to be completely infected with typical lesions at 7 days after inoculation. The morphological characteristics of the reisolates were identical with the original

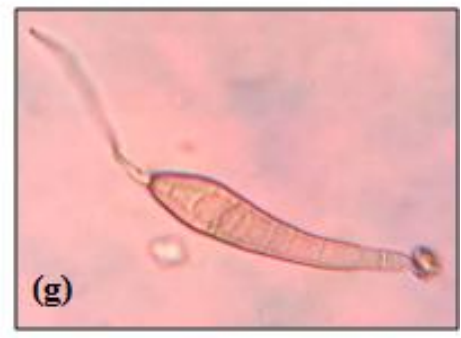

isolates. The results showed that $C$. cassiicola was the causal agent of the disease.

In conclusion, the isolated pathogen $C$. cassiicola causing Corynespora spot in chilli was new and emerging pathogen in chilli therefore our furthere studies on this pathogen, its epidemiology disease prevalence and its management practices.

\section{References}

Chowdappa, P., Madhura, S., Nirmal Kumar, B. J., Mohan Kumar, S. P., and Hema, 
K. R. 2014. Phytophthora boehmeriae revealed as the dominant pathogen responsible for severe foliar blight of Capsicum annuum in South India. Plant Diseases, 98: 90-98.

Ellis MB, Holliday P. 1971. Corynespora cassiicola. In: CMI description of pathogenic fungi and bacteria. Kew (UK): CMI; p. 303.
Indiastat, 2011-12. www.indiastat.com

Kwon, JH, Kang SW, Kim, JS and Park CS.2001.First report of corynospora leaf spot in pepper caused by Corynospora cassicola in Korea, The Plant Pathology Journal.17(3):180-183.

Wei CT. 1950. Notes on Corynespora. CMI Mycol Pap. 34:1-10.

\section{How to cite this article:}

Veera Suresh, N. Sumalatha, Vikas Kumar Ravat and Amitava Basu. 2017. First Report of Corynespora Leaf Spot Caused By Corynespora cassiicola on Chilli in West Bengal, India. Int.J.Curr.Microbiol.App.Sci. 6(8): 3216-3219. https://doi.org/10.20546/ijcmas.2017.608.383 